\title{
The Effect of Direct-Focused and Unfocused Written Corrective Feedback toward Freshmen Foreign Language Writing
}

\author{
Muh Junaidi ${ }^{1}$, Marham Jupri Hadi ${ }^{2}$ \\ 11muhjunaidi13@gmail.com, ${ }^{2}$ marhamhadi@gmail.com \\ 1,2 UNW Mataram
}

\begin{abstract}
This study aims at finding out the effect of Direct-Focused and Direct-Unfocused Written Corrective Feedback in improving freshmen essay writing. The use of preposition, article and past tense were mainly investigated in students' revision text and new pieces of essay writing. The study uses an experimental method and true-experimental design. Data collected from 60 students that consist of DIRECT-focused, Direct-unfocused, and without feedback. Data collected are analyzed by two-way ANOVA using SPSS 21. The study found the significant effect of Direct-Focused CF. Likewise, using Direct-Unfocused CF has positive effect. Both groups outperform in revision and new pieces of writing than group without corrective feedback. In addition, there is positive interaction effect among the use of such corrective feedback and exposure. For that reason, it seems that is evidence underpinning the importance of such feedbacks and exposure in increasing students' writing accuracy at using any grammatical items. Further study needs to be held in order to reveal the relationship or effect of students' motivation, perception and engagement and typology of feedback in improving students writing performance.
\end{abstract}

Keywords: corrective feedback, direct-focused and direct unfocused

\section{INTRODUCTION}

Writing skill is one of the most difficult things for learners in foreign language context. It requires more complex cognitive skill including critical thinking and scientific sensibility. In undergraduate level, most of learners are stressed out when they are asked to written an essay. In general, the problem has to do with what to write and how to write. The former require the learners to read various sources related to given topics. The latter demands them about the way to write dealing with essay structures and linguistics features of different kinds of essays. Apart from the problems, in order to write, teachers need to give input that is not only positive evidence but also negative evidence (feedback) of the target language.

Giving feedback for learners' writing has been main issue whether or not written corrective feedback (henceforth WCF) has positive effect in improving students' writing. Some researchers claim that WCF has no positive effect for developing the learners' accuracy writing (Truscott, 1996, 2007; Kepner, 1991; Sheppard, 1992). Otherwise other researchers advocates the importance of WCP in underpinning the accuracy revised writing (Ferris, 1999; 2006; Aswhell, 2000, and Hyland, 2006) and new pieces of writing (Bitchener, 2008, 2009; Ellis, sheen, Takashima, and Murakami, 2008; and others). 
Current studies have been concerned with the effectiveness of different types of written corrective feedback in developing learners' accuracy writing including direct and indirect, focused and unfocused and metalinguistic feedback. For examples, the studies aim at finding different effect of focused and unfocused WCF on grammatical accuracy of English articles (Farrokhi \& Sattarpour, 2011); of the third person singular's morpheme for Verbs (Saeb, 2014). Both advocate the effectiveness of the feedback. However, the studies by no means only focus on single item of grammar. Furthermore, they did not explain if each of feedback was directly or indirectly given. This also crucial variable affect such feedbacks.

Most of freshmen have difficulties when they are asked to write an essay. Such problems mainly have to do with what and how to write. However, the issues also include the writing process. In this case, teachers may encounter the problem on deciding what types of feedback that should be implemented in teaching writing. That problem is one of the importance for conducting this study. In addition, lack of study on the effect of direct focused and unfocused feedback in EFL context, it is needed for conducting study on the effect such WCFs on students' essay writing in terms grammatical accuracy using preposition, simple past, and articles.

The study aims at finding out the effect of direct-focused and unfocused written corrective feedback towards freshmen foreign language writing held at English Department of faculty of education and Training UNW Mataram. The linguistic errors that receive CF focus on the use of prepositions, past simple tenses, and articles. The finding of this study is to reveal comparison effect of such feedback towards students essay writing. In addition, the result may provide empirical evidence for teachers in EFL context about the type of effective feedback that can be used in the classroom.

A number of previous studies have been conducted pertaining to the importance and effectiveness of written corrective feedback to learner's grammatical error. Previous studies claiming that grammar correction has no effect to improve the accuracy of L2 writing is Truscott (1996, 2007), Kepner (1991), and Sheppard (1992). On the other hand, these specific studies advocating on the importance and effectiveness of written corrective feedback were conducted by (Bichener and Knoch, 2008a; Chandler, 2003; Sheen, 2007; Lalande, 1982; and Ellis at al. 2008).

Grammar correction has no correlation with writing instruction (Truscott, 1997). It is due to some these reasons: a) research evidence does not show that the grammar correction is effective; b) grammar correction has significant harmful effect. Similarly, Kepner (1991) provided information by conducting a study with intermediate Spanish as a foreign language with two strategies of feedback. The study found that there was no significance difference in accuracy. 
Furthermore, it is in line with Sheppard (1992) who categorized this case as avoidance strategies of the students who were often given correction by leading students in limiting the complexity of their writing. In short, Tuscott (1996), Sheppard (1992), and Kepner (1991) suggested that error correction or providing student with negative evidence involving interpersonal interaction has an effect in teaching writing.

It is contrast with these studies the effectiveness of written corrective feedback to enhance students' grammatical accuracy, such as (Chandler, 2003; Sheen, 2007; Ellis at al. 2008; Bitchiner and Knoch 2008a; and Chandler, 2003). These studies specifically examined the effectiveness of various kinds of error feedback for improvement in the accuracy and fluency of second language students' writing. Chandler (2003, p. 290) found evidence that after the correction or by underlining students errors and then letting students self-correction all the grammatical and lexical errors in the autobiographical writing of high intermediate to advanced ESL undergraduates, followed by revision gave evidence that there were significant improvements in both accuracy and fluency. In other words, Chandlers' study found both direct correction and simple underlining of error are significantly effective to describe the type of error.

The work of Sheen (2007) indicate that the effect of focused written corrective feedback on intermediate ESL learners' acquisition of English articles, to discover if there is a difference between in the effect of direct correction with and without metalinguistic, and to investigate to what extent learners' language analytic ability mediate the effectiveness of written corrective feedback. The study design was quasi-experimental with pre-test-treatment-post-test, delayed post-test structure. The study was held in six intact classrooms in an American Language Program (ALP) of Community College in the United States. The participants of the study were five native English-speaking American teachers and 111 intermediate-level students. The target structure was only English articles.

A study by Sheen (2007) shows that focused written corrective feedback on article errors produced (articles) was a positive effect on acquisition. Another finding of this study was that two types of corrective feedback; direct correction with metalinguistic comment was superior to direct correction without metalinguistic comment. This is in line with Schmidt $(1990,2001)$ who distinguished awareness at the level of awareness, such as conscious rule awareness, arising from understanding and strongly facilitates learning. The last finding of this study found that learners with high level of language analytic ability benefits more from both types of corrective feedback. This study gave positive evidence for students with higher aptitude for language analysis. 
However, it was found with direct correction and with metalinguistic' comment (Sheen, 2007, p. 276).

It is also needed to be clarified, the correlation between corrective feedback and SLA, especially in terms of aptitude. By no mean, what Sheen found that the higher the aptitude, the more effective is the direct correction with metalinguistic comment. Saville-Troike (2006) notes that "learners who categorized as field independent/FI has preferences of their cognitive process to be particularistic, inductive, focused on form and analytic" (p. 97). Subsequently, why should we provide students with direct correction? The students in this category may analyze their error by themselves. It is in contrast with learners who are field dependent. They tend to be holistic, global, deductive, more focused on meaning. It is not stated in Sheen's study if the study had categorized the participants whether or not they are field independent.

Another study conducted by Bitchener, Young, \& Cameron (2005) is on the effect of different types of corrective feedback in ESL students' writing. They examined to what extent the type of corrective feedback on linguistic errors determine the accuracy performance in new pieces of writings. The participants of the study were 53 post-intermediate TESOL (migrant) learners who had only just entered a post-intermediate TESOL program. The study divided the participants into three treatment groups based on the time of taking the program; a full-time post-intermediate for 20 hours per week, a part time post intermediate for 10 hours per week, and a part time postintermediate for 4 hours class per week.

Bitchener at al. (2005) showed that the combination of full, explicit written feedback and one to one conference feedback enable the learners to use the past simple tense and the definite article with significantly greater accuracy in a new pieces of writing than that was the case with their use of preposition. The finding that there is improvement in new pieces of writings rather that a revised draft is in line with (Ashweel, 2000; Fathman and Walley, 1990; Ferris and Roberts, 2001; Bitchener, 2008). Furthermore, Bitchener (2008) found that written corrective feedback had significant effect on improving accuracy in the use of two functional uses of the English article system.

Ellis, Sheen, Murakami, \& Takashima (2008) arrange a study to find the effect of focused and unfocused written corrective feedback in an English as Foreign language context. Ellis at., al (2008) studied if written corrective feedback help Japanese learners of English to become more accurate in the use of English indefinite and definite articles to express first and second mention, and to discover if there is a difference between focused and unfocused written corrective feedback on learners' accuracy in using those articles. The study used a quasi-experimental design in which 
intact classes were involved two experimental groups; focused group $(\mathrm{N}=18)$, unfocused group $(\mathrm{N}=18)$, and a control group $(\mathrm{N}=13)$. Therefore, the sum of samples were 49 participants in total.

Ellis at al. (2008) found that both experimental groups who had given focused and unfocused written corrective feedback showed improvement from pre-test to post test in which both got better to correct the articles error in the sentence than the control group. Furthermore, the study provided some evidence that there were not significant different between focused and unfocused groups in either the narrative writing tests or error correction. In other words, both types of feedback showed equal effect of students' accuracy in using the articles. This study trying to provide more clues about discovering the difference between the effect of focused and unfocused corrective feedback failed. Subsequently, further research is needed to convince if there is a difference between these two types of feedback.

The recent studies indicate lack of studies on the effect of direct-focused corrective feedback towards students essay writing held in EFL context. Based on the aforementioned theories and recent studies, the aim of this study is to find out the effect of direct focused and unfocused written corrective feedback of freshmen at UNW Mataram. The following hypotheses will be tested: 1) HO: There is no effect direct-focused and unfocused written corrective feedback of students essay writing; 2) H1: there is significant effect of direct-focused and unfocused written corrective feedback of students essay writing; 3) H2: There is no significant interaction effects between written corrective feedback in revised texts and a new composition.

\section{RESEARCH METHOD}

This study uses true experimental research design. The participants of the study are 350 students of English Education department, UNW Mataram. 60 samples are assigned and selected for those populations according to their TOEFL score. Next, the samples are divided into three groups according their TOEFL score, one direct-focused group and a direct-unfocused group (as experimental group) and one group without written corrective feedback. The data are collected by pre-test and post-test. Each group will be given pre-test and post-test. However, only experimental group will get the treatment. Data collected are analyzed by using SPSS. For inferential statistics, Factorial Analysis of Variance (ANOVA) will be used for comparing the means among the groups. It is used for finding variance between groups of WCF and variance due to interaction effect of WCF and students grammatical accuracy in essay writing. 


\section{FINDINGS AND DISCUSSION}

Statistical assumptions must be fulfilled for conducting an ANOVA analysis, namely normal distribution and homogeneity variance.

Table 1. Summary result of Normality Testing Tests of Normality

\begin{tabular}{|l|r|r|r|r|r|r|}
\hline \multirow{2}{*}{} & \multicolumn{3}{|c|}{ Kolmogorov-Smirnov ${ }^{\mathrm{a}}$} & \multicolumn{3}{c|}{ Shapiro-Wilk } \\
\cline { 2 - 7 } & Statistic & \multicolumn{1}{|c|}{ Df } & \multicolumn{1}{c|}{ Sig. } & Statistic & \multicolumn{1}{c|}{ Df } & \multicolumn{1}{c|}{ Sig. } \\
\hline $\begin{array}{l}\text { Standardized Residual for } \\
\text { Score }\end{array}$ &, 089 & 120 &, 022 &, 986 & 120 &, 240 \\
& & & & & & \\
\hline
\end{tabular}

a. Lilliefors Significance Correction

Table 1 shows that sig vallue of kolmogrof-Smirnof and Shapiro-Wilk is .022 and .240. The values obtained are higher than .05. it reveals that data did not violate from the normal distribution.

Table 2. Homogenity of Variance Testing

\begin{tabular}{|c|c|c|c|}
\hline \multicolumn{4}{|c|}{ Levene's Test of Equality of Error Variances ${ }^{\text {a }}$} \\
\hline Dependent Variable: & $\begin{array}{l}\text { Students' writing } \\
\text { achievement }\end{array}$ & & \\
\hline F & df1 & df2 & Sig. \\
\hline 3,307 & 5 & 114 &, 008 \\
\hline \multicolumn{2}{|c|}{ Tests the null hypothesis that the error variance of the dependent variable is equal across groups. } \\
\hline
\end{tabular}

Levene's test was used for measuring the equality of variances. Table 2 indicates that homogenity variance was 0.08 . It is greater than .05 . So variances are equally homogenous.

Table 3. Between subject effects

Tests of Between-Subjects Effects

Dependent Students' writing achievement

Variable:

\begin{tabular}{|c|c|c|c|c|c|}
\hline Source & Type III Sum of Squares & df & $\begin{array}{c}\text { Mean } \\
\text { Square }\end{array}$ & F & Sig. \\
\hline
\end{tabular}




\begin{tabular}{|c|c|c|c|c|c|}
\hline Corrected & $2128.367^{\mathrm{a}}$ & 5 & 425,673 & 40,118 &, 000 \\
Model & 669312,033 & 1 & 669312,033 & 63080,003 &, 000 \\
Intercept & 495,717 & 2 & 247,858 & 23,360 &, 000 \\
Feedback & 1484,033 & 1 & 1484,033 & 139,864 &, 000 \\
Exposure & 148,617 & 2 & 74,308 & 7,003 &, 001 \\
Feedback $*$ & 1209,600 & 114 & 10,611 & & \\
Exposure & 672650,000 & 120 & & & \\
Error & 3337,967 & 119 & & & \\
Total & Corrected & & & & \\
Total & & & & & \\
\hline
\end{tabular}

a. $\quad$ R Squared $=.638$ (Adjusted R Squared $=.622$ )

As seen in table 3, sig value of direct-focused and direct-focused corrective feedback is .000. It is greater than 0.05 . In other words, those feedbacks significantly improve students' performance at using preposition, simple past and preposition. For that reason, the first null hypothesis on does the corrective feedback improve students' accuracy at using such grammatical items? Is rejected. Furthermore, table 3 indicates that value obtained on feedback exposures (revising old text and new pieces of text) was .000. It is lesser than .05. It can be evidence for rejection the second null hypothesis. Thus, an alternative hypothesis is accepted, i.e. there is significant effect of types writing exposure. In other words, student getting opportunity for revising and writing new text outperform than the student who were not given chance for revising or writing a new pieces of text.

Regarding with research question 3, as seen in table 3, significant value is .001. It means that it is less than .05 . it indicates that there is significance interaction effects between types of corrective feedback and type of writing exposure in terms of revising the same text and writing a new pieces of the text.

Table 4. Descriptive Statistics

Descriptive Statistics

\begin{tabular}{|c|c|c|c|c|}
\hline $\begin{array}{l}\text { Dependent } \\
\text { Variable: }\end{array}$ & $\begin{array}{l}\text { Students' writing } \\
\text { achievement }\end{array}$ & & & \\
\hline \multicolumn{2}{|c|}{ Written Corrective Feedback } & Mean & $\begin{array}{c}\text { Std. } \\
\text { Deviation }\end{array}$ & $\mathrm{N}$ \\
\hline \multirow{5}{*}{$\begin{array}{l}\text { Direct-Focused } \\
\text { Corrective } \\
\text { Feedback } \\
\text { (DFCF) } \\
\text { Direct- } \\
\text { Unfocused }\end{array}$} & Revision Text & 71,40 & 2,234 & 20 \\
\hline & New Text & 81,35 & 3,990 & 20 \\
\hline & Total & 76,38 & 5,964 & 40 \\
\hline & Revision Text & 72,55 & 3,316 & 20 \\
\hline & New Text & 79,15 & 2,033 & 20 \\
\hline
\end{tabular}




\begin{tabular}{|cc|c|c|c|} 
Corrective & Total & 75,85 & 4,306 & 40 \\
Feedback & Revision Text & 69,55 & 4,211 & 20 \\
Conventional/ & New Text & 74,10 & 3,144 & 20 \\
without & Total & 71,83 & 4,332 & 40 \\
Feedback & Revision Text & 71,17 & 3,523 & 60 \\
(CWF) & New Text & 78,20 & 4,360 & 60 \\
& & & & \\
Total & Total & 74,68 & 5,296 & 120 \\
\hline
\end{tabular}

As shown in Table 4 studentsz with DFCF and DUCF outperform in revision text and new text.

Table 5. Multiple comparison

\section{Multiple Comparisons}

Dependent Students' writing

Variable: achievement

Tukey HSD

\begin{tabular}{|c|c|c|c|c|c|}
\hline \multirow[t]{2}{*}{ (I) Written Corrective Feedback } & \multirow{2}{*}{$\begin{array}{c}\text { Mean } \\
\text { Difference } \\
(\mathrm{I}-\mathrm{J})\end{array}$} & \multirow[b]{2}{*}{$\begin{array}{l}\text { Std. } \\
\text { Error }\end{array}$} & \multirow[b]{2}{*}{ Sig. } & \multicolumn{2}{|c|}{$\begin{array}{c}95 \% \\
\text { Confidence } \\
\text { Interval } \\
\end{array}$} \\
\hline & & & & $\begin{array}{l}\text { Lower } \\
\text { Bound }\end{array}$ & $\begin{array}{l}\text { Upper } \\
\text { Bound }\end{array}$ \\
\hline
\end{tabular}




\begin{tabular}{|c|c|c|c|c|c|c|}
\hline $\begin{array}{l}\text { Direct- } \\
\text { Focused }\end{array}$ & $\begin{array}{l}\text { Direct-Unfocused } \\
\text { Corrective }\end{array}$ & ,53 & ,728 & 752 & $-1,20$ & 2,25 \\
\hline Corrective & Feedback (DUCF) & & & & & \\
\hline $\begin{array}{c}\text { Feedback } \\
\text { (DFCF) }\end{array}$ & $\begin{array}{c}\text { Conventional/ } \\
\text { without Feedback } \\
(\mathrm{C} / \mathrm{WWF})\end{array}$ & $4.55^{*}$ & ,728 & ,000 & 2,82 & 6,28 \\
\hline $\begin{array}{l}\text { Direct- } \\
\text { Unfocused }\end{array}$ & $\begin{array}{l}\text { Direct-Focused } \\
\text { Corrective }\end{array}$ &,- 53 & ,728 & ,752 & $-2,25$ & 1,20 \\
\hline Corrective & Feedback (DFCF) & & & & & \\
\hline $\begin{array}{l}\text { Feedback } \\
\text { (DUCF) }\end{array}$ & $\begin{array}{c}\text { Conventional/ } \\
\text { without Feedback } \\
(\mathrm{C} / \mathrm{WWF})\end{array}$ & $4.03^{*}$ & ,728 & ,000 & 2,30 & 5,75 \\
\hline \multirow{3}{*}{$\begin{array}{c}\text { Conventional/ } \\
\text { without } \\
\text { Feedback } \\
\text { (C/WWF) }\end{array}$} & $\begin{array}{l}\text { Direct-Focused } \\
\text { Corrective }\end{array}$ & $-4.55^{*}$ & ,728 & ,000 & $-6,28$ & $-2,82$ \\
\hline & Feedback (DFCF) & & & & & \\
\hline & $\begin{array}{l}\text { Direct-Unfocused } \\
\text { Corrective } \\
\text { Feedhack (DUCF) }\end{array}$ & $-4.03^{*}$ & ,728 & ,000 & $-5,75$ & $-2,30$ \\
\hline
\end{tabular}

Since independent variables consist of three level direct-Focused Corrective feedback (DFCF), direct-unfocused corrective feedback (DUCF), and without corrective feedback (WCF), it is needed to hold post-hoc analysis. As seen in Table 6, interaction effect between DFCF and DUCF is 752. It is lesser than .05. Therefore, the interaction is less significant. Meanwhile the interaction between group without Corrective feedback with either WCF and WUCF is .000 and .000 . It indicates the sig value is lesser than .05 . Therefore, interaction effect of C/WF is significant toward DFCF and DUCF. For that reason, $\mathrm{H} 3$ is rejected. Therefore, there is significant interaction effects of Direct-focused corrective feedback, Direct-unfocused corrective feedback and without corrective feedback in improving student's grammatical accuracy in Essay Writing.

The study finding on the effectiveness of direct-focused and direct-unfocused writing corrective feedback corroborate with previous studies held by Bitchener \& Knock, 2010; Chandler, 2003; Sack \& Polio, 2007; Bitchener, 2008 and many others. It contradicts with Truscott studies (1996); Wahyuni, 2018; Truscott \& Hsu, 2008 claiming that provision of correction has nothing to do with students writing development. In addition, the study found that there is significant effect direct-focused and direct-unfocused corrective on either revised texts or new pieces of writing. The finding is in line with the previous studies revealing the positive effect of feedback on revised text and a new composition (Bitchener and Knoch, 2008; Ellis, at al, 2008; Sheen, Wright, and Modalawa, 2008; Storch and Wigglesworth, 2010; and Van Beuningen, De Jong and Kuiken, 2008, 2012). It must be recognized that the students getting feedback and 
opportunity to revise the same text and to write a new composition outperform than the group without feedback and exposures for revision and writing a new text.

\section{CONCLUSION}

Based on the study finding, both type of written corrective feedback; direct-focused and direct-unfocused written corrective feedback, and type of writing exposures in the forms revising and rewriting have positive impact in improving students' writing accuracy at using preposition, article and simple past. Furthermore, interaction effect between those feedback and writing exposure significantly affect the students' performance writing. For that reason, it is crucial for teachers to provide either feedback or exposure in order to increase students' writing accuracy at using any grammatical items. The evidence seems to indicate the importance of such feedback and exposure in imporving students' writing accuracy at using any grammatical items in English Foreign language contexts. Apart from the study finding, it is pivotal for further study on analyzing students' motivation, perception, engagement and written corrective feedback.

\section{REFERENCES}

Afraz, Shahram. (2012). The effect of focused written corrective feedback of contrastive analysis on EFL learners acquisition of verb tenses. Journal of educational and instructional studies in the world, 2(4), 48-61.

Ashwell, T. (2000). Patterns of teacher response to student writing in multi-draft composition classroom: is content feedback followed by form feedback the best method? Journal of second language writing, 9 (3), 227-257.

Bichener, J. (2008). Evidence in support of written corrective feedback. Journal of second language writing. 17, 112-118.

Bitchener, J., \& Knoch, U. (2008). The value of written corrective feedback for migrant and International students, Language Teaching Research Journal, 12:409-31

Bitchener, J., \& Knoch, U. (2009). The relative effectiveness of different types of direct written corrective feedback. System, 37(2), 322-329.

Bitchener, J. \& Knoch, U. (2009a). The relative effectiveness of different types of direct written corrective feedback. System, 37, 322-329.

Bitchener, J. \& Knoch, U. (2009b). The value of a focused approach to written corrective feedback. ELT Journal, 63(3), 204-211.

Byrne, D. (1991). Teaching Writing Skills. Hong Kong: Longman.

Chandler, J. (2003). The efficacy of various kinds of error feedback for improvement in the accuracy and fluency of L2 student writing. Journal of Second Language Writing, 12(3), 267-296. 
Ehlsen, E., and Lundth, N. (2007). Teaching writing and theory in practice: A study of ways of working with writing in the 9th grade. Department of curriculum studies and communication.

Ellis, R. (1994). The study of second language acquisition. Oxford: Oxford University Press.

Ellis, R.,Sheen, Y., Murakami, M., \& Takashima, H. (2008). The effect of focused and unfocused written corrective feedback in an English as foreign language context. 36, 353-371.

Farrokhi, F., \& Sattarpour, S. (2012). The effects of direct written corrective feedback on improvement of grammatical accuracy of high-proficient L2 learners. World Journal of Education, 2, 49-57.

Fathman, A., and Whalley, E. (1990). Teacher respond to student writing: focus on form versus content. In B. Kroll (Ed.), second language writing: research insights for the classroom (pp. 178-190). Cambridge: Cambridge University Press.

Ferris, D. (2003). Responds to student writing. Implication for second language students. New Jersey: Lawrence Erlbaum Associates.

Ferris, D., and Roberts, B. (2001). Error feedback in L2 writing classes. How explicit does need to be? Journal of second language writing 10 (3), 161-184.

Gass, S. M., and Selinker, L. (2001). Second Language Acquisition: An Introductory Course (3rd Ed.). Mah-wah, New Jersey: Erlbaum. Hedge, T. (1991). Writing. Hong Kong: Oxford University Press.

Hyland, K., and Hyland, F. (2006). Feedback on second language students' writing. Language teaching 39 (2), 83-101.

Kepner, C. G. (1991). An experiment in the relationship of types of written feedback to the development of second-language writing skills. Modern Language Journal, 75, 305-313.

Lalande, J. F., II (1982). Reducing composition errors: An experiment. Modern Language Journal, $66,140-149$.

Lee, I. (1997). ESL learners' performance in error correction in writing: some implication for college level teaching. System, 25, 465-477.

Hatch, E. M., and Lazaraton, A. (1991). The research manual: Design and statistics for applied linguistics. New York: Newbury House.

Nunan, D., and K. M. Bailey. (2009). Exploring second language classroom research: A comprehensive guide. Boston: Heinle, Cengange Learning.

Philips, D. (2003). Preparation course for the TOEFL test. White plain NY: Pearson Education, Inc.

Purnawarman, P. (2011). Impact of teacher feedback on esl/efl students' writing. unpublished doctoral dissertation, .Institute Polytechnique Institute and State University.

Saville-Troike, M. (2006). Introducing Second Language Acquisition. Cambridge. Cambridge University Press.

Sheen, Y. (2007). The effect of focused written corrective feedback and language aptitude on ESL learners' acquisition of articles. TESOL Quarterly, 4, 255-283. 
Sheen, Y., Wright, D., \& Moldawa, A. (2009). Differential effects of focused and unfocused written correction on the accurate use of grammatical for ms by adult ESL learners. System, 37, 556-569.

Schmidt, R. (1990). The role of consciousness in search of useful definition for applied linguistics. AILA Review 11, 11-26.

Schmidt, R. (2001). Attention. In P. Robinson (Ed.), cognition and second language instruction (pp.3-32). Cambridge. Cambridge University Press.

Sheppard, K. (1992). Two feedback types: Do they make difference? RELC journal 23 (1), 103 110.

Storch, N. And Wigglsworth, G. (2010). Learners' processing, uptake and retention of corrective feedback on writing. Case Studies, Studies in Second Language Acquisition 32, 1-32.

Truscott, J. (1996). The case against grammar correction in L2 writing classes. Language Learning 46, 327-369. http://dx.doi.org/10.1111/j.1467-1770.1996.tb01238.x

Truscott, J. (2007). The effect of error correction on learners' ability to write accurately. Journal of second language writing, 16, 255-272. http://dx.doi.org/10.1016/j.jslw.2007.06.003

Van Beuningen, C. G., De Jong, N.H. and Kuiken, F. (2012). Evidence on the effectiveness of comprehensive errors in second language writing, Language Learning, 62, 1-41. 